UDC 571.27; 616.366-002; 615.322.

doi: https://doi.org/10.15407/ubj92.04.077

\title{
ANTI-INFLAMMATORY AND HEPATOPROTECTIVE EFFECTS OF POLYHERBAL COMPOSITION IN PATIENTS WITH CHRONIC CHOLECYSTITIS
}

\author{
M. GAHRAMANOVA', ${ }^{1,2}$ I. KHALILOVA ${ }^{3}$, A. OMAROV ${ }^{3}$, \\ Ya. SUSAK ${ }^{4}$, M. RUDYK ${ }^{2}$, L. SKIVKA ${ }^{2 \bowtie}$ \\ ${ }^{1}$ Nargiz Medical Center, Baku, Azerbaijan; \\ ${ }^{2}$ ESC "Institute of Biology and Medicine", \\ Taras Shevchenko National University of Kyiv, Ukraine; \\ ${ }^{3}$ Department of Life Sciences \& Center for Cell Pathology Research, \\ Khazar University, Baku, Azerbaijan; \\ ${ }^{4}$ Bogomolets National Medical University, Kyiv, Ukraine; \\ 凶e-mail: realmed@i.com.ua
}

Received: 21 November 2019; Accepted: 15 May 2020

Herbal preparations are widely used in the complementary treatment of inflammatory diseases including hepatobiliary disorders, among which chronic cholecystitis is one of the most common. This study was aimed to investigate the effect of the water extract from polyherbal composition consisting of eight medicinal plants (Helichrysum arenarium, Mentha piperita, Calendula officinalis, Taraxacum officinale, Polygonum aviculare, Matricaria chamomilla, Portulaca oleracea, Hypericum perforatum) on biochemical and haematologic indices as well as on immune reactivity parameters in patients with chronic cholecystitis. It was found that consumption of polyherbal tea during 45 days was followed by normalization of liver biochemical indices (serum level of cholesterol, alanine aminotransferase and aspartate aminotransferase activity, total and unconjugated bilirubin levels and diminution of hematological (leukocytosis, increased erythrocyte sedimentation rate and neutrophil-to-lymphocyte ratio) and immunological (increased serum level of pro-inflammatory cytokines) signs of systemic inflammation in patients with hepatobiliary disorder. The results of the research showed that the studied polygerbal composition can be recommended as a component of the complementary therapy for patients with chronic cholecystitis.

Keywords: chronic cholecystitis, polyherbal composition, cholesterol, cytokines, hepatoprotective effect, immunomodulation.

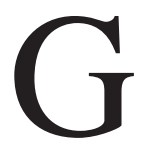
allstone disease (cholelithiasis) remains one of the most cutting edge medical problems due to the steady increase in its frequency over the world. In the developed countries, cholelithiasis occurs in $10-20 \%$ of the population, and in $30-40 \%$ of elderly and old aged people [1]. Chronic cholecystitis (CC) is long-standing gallbladder inflammation that is associated with cholelithiasis in approximately $95 \%$ of cases. Pro-inflammatory activation of local (in gallbladder mucosa) and circulating immune cells with the overexpression of mediators such as endogenous alarmins (S-100) and pro-inflammatory cytokines is considered as one of the putative pathogenetic mechanisms of the disease [2]. Neutrophils are recruited from circulation to the mucosa and affect interstitial Cajal-like cells, leading to impaired gallbladder motility. So, increased neutrophil-to-lymphocyte ratio (NLR) is a valuable prognostic factor of cholecystitis severity [3]. The first and top priority aim of treatment of chronic cholecystitis is the diminution of the inflammatory process, normalization of the bile secretion, concentration, and excretion, and prevention of gallstone formation. Herbal medicine remedies have an ability

(C) 2020 Gahramanova M. et al. This is an open-access article distributed under the terms of the Creative Commons Attribution License, which permits unrestricted use, distribution, and reproduction in any medium, provided the original author and source are credited. 
to reduce gallbladder inflammation and are successfully used in the alternative treatment of gallbladder diseases [4]. Main objectives of the herbal treatment of chronic cholecystitis include improvement of bile discharge, elimination of spasms of the gallbladder and bile ducts, dissolution of the existing gallstones and prevention of their formation, as well as hepatoprotective and anti-inflammatory effects. One of the medicinal plants which has been widely investigated during the last two decades due to the unique properties is purslane (Portulaca oleracea). Portulaca oleracea is a cosmopolitan annual weed that has been listed in the World Health Organization as one of the most used medicinal plants. Pharmacological effects of $P$. oleracea are widely documented and include hypoglycemic, hypocholesterolemic, antidiabetic, antipyretic, antiasthma, hepatoprotective, anti-inflammatory action etc. [5]. Phytochemicals of $P$. oleraceae include polyphenolics, flavonoids, alkaloids, tannins, saponins, vitamins A, E, C, fiber, coenzyme Q10, carotene, essential fatty acids, as well as calcium, zinc, potassium, sodium, manganese, iron, phosphorus and selenium [6]. This medicinal plants is more commonly used in the form of monocomponent remedy. Though, herbal mixtures containing a combination of different medicinal plant have been reported to have better biological activities than isolated active compounds and monocomponent preparations due to the synergistic effect of their constituents [7]. Polyherbal composition, which combine pharmacological potential of eight medicinal plants (Helichrysum arenarium, Mentha piperita, Calendula officinalis, Taraxacum officinale, Polygonum aviculare, Matricaria chamomilla, Portulaca oleracea, and Hypericum perforatum) was developed in Nargiz Medical center (Republic of Azerbaijan) for the use as herbal tea and was patented in Eurasian Patent Organization, EAPO (EAPO Patent $\mathrm{N}$ 023163). This study was aimed to investigate the effect of polyherbal composition consisting of eight medicinal plants on biochemical and haematologic indices as well as on immune reactivity parameters in patients with CC.

\section{Materials and Methods}

Polyherbal composition. Studied polyherbal composition includes Caléndula officinális (flowers), Polýgonum aviculáre (flowers, leaves and stems), Hypericum perforatum (flowers and stems), Taráxacum officinále (roots), Matricāria chamomīlla (flowers), Helichrýsum arenárium (flowers), Méntha piperíta (leaves), P. oleracea (roots and leaf) which were taken in equal parts [8].

Patients and study design. Seventy six patients with CC without comorbidity associated with cytolysis (e.g. acute hepatitis A virus infection) who were appealed to Nargiz Medical Center of Baku, Azerbaijan for medical aid over a 2019 year were enrolled in the study (Table 1). Individuals were excluded if they had any of the following: received any medical treatment during the last month before the inclusion in the study; had been diagnosed with acute cholecystitis; were pregnant or breast-feeding. Those, who were not able to follow the instructions properly, were also excluded. The study was approved by the National Committee of Azerbaijan on the Bioethics of Scientific Knowledge and Technology at UNESCO (protocol N5, 12.11.2019). Written, informed consent was obtained from all patients according to a protocol of the National Committee of Azerbaijan on the Bioethics of Scientific Knowledge and Technology. All patients regardless of disease severity were included in the study.

The components of polyherbal composition were sealed in a teabag ( $5 \mathrm{~g}$ ). Participants were provided with standard vessels (the volume of $200 \mathrm{ml}$ ) and were instructed to infuse the teabag in hot water in the vessel for 30 minutes, and then to drink the tea. They were instructed to drink the tea trice a day before the eating, for 45 days. Patient outcomes were recorded at baseline, and at the 30 days post-intervention follow-up. The outcomes of this study were haematologic indices, laboratory tests on liver, cytokine profile of peripheral blood, plasma myeloperoxidase, its activity and specific activity. Data on any unfavorable events were assembled at each visit.

Twenty healthy adults were recruited to participate in the study as a control group. Exclusion criteria was a history of somatic disease. Approval was obtained from the Ethical Committee of the Na-

\section{Table 1. Baseline characteristics of the studied} group

\begin{tabular}{|l|c|}
\hline Female, \% & 63.1 \\
\hline Female age range, years & $22-70$ \\
\hline Male, \% & 36.9 \\
\hline Male age range, years & $20-62$ \\
\hline Calculous cholecystitis, \% & 61 \\
\hline Acalculous cholecystitis, \% & 39 \\
\hline
\end{tabular}


tional Committee of Azerbaijan on the Bioethics of Scientific Knowledge and Technology at UNESCO, and consent was obtained from all healthy persons prior to the enrolment.

Haematologic assay. Haematologic indices included total count of leukocytes, segmented neutrophil (\%), lymphocytes (\%), eosinophils (\%), monocytes (\%) and NLR ratio, and were examined with the use of haematologic analyzer RT-7600 (Rayto Electronics, China) in accordance with manufacturer reccomendations. In addition, all mentioned above haematologic indices along with band (immature) neutrophil (\%) were determined in peripheral blood smears by routine manual method.

Biochemical assay. Biochemical indices included levels of serum cholesterol, alanine aminotransferase (ALT), aspartate aminotransferase (AST), total bilirubin (TBR), conjugated [direct reacting] and unconjugated [indirect reacting] bilirubin, and were examined with the use of Biochemical analyser Kenza Max BioChemistry (Biolabo SAS, France) in accordance with manufacturer recommendations.

Cytokine profile. Serum levels of interleukin$1 \beta,-6$ and -4 (IL1 $\beta$, IL6 and IL4) were examined using ELISA kits (Vector Best, Russia) according to the manufacturer recommendations.

Myeloperoxidase detection. The total concentration of myeloperoxidase (MPO) and the concentration of active enzyme in the EDTA-blood plasma were measured by sandwich variant immunoassay (ELISA) combined with SIEFED (Specific Immunological Extraction Followed by Enzymatic Detection) analysis [9]. MPO was bound via a specific monoclonal capturing antibody (Abcam, UK) to an ELISA plate, and its activity was measured using a substrate mixture ( $20 \mu \mathrm{mol}$ of hydrogen peroxide, $50 \mu \mathrm{mol}$ of Amplex Red (10-acetyl-3,7-dihydroxyphenoxazine) in $50 \mathrm{mM}$ phosphate buffer, $\mathrm{pH} 7.4$ containing $50 \mathrm{mmM} \mathrm{NaBr}$ ) which gives a fluorescent product resorufin, measured using. The excitation wavelength is $544 \mathrm{~nm}$ and the wavelength of the emitted light is $590 \mathrm{~nm}$. The concentration of active MPO (ng/ml) was determined according to a calibration curve constructed using standard solutions of human MPO (PLANTA çAustria). The plate was then washed and rabbit monoclonal antibodies against human MPO - detecting antibody (Abcam, United Kingdom) - was added. Immune complexes were visualized using biotinylated goat antibodies against rabbit immunoglobulin Fc fragment and avidin-alkaline phosphatase conjugate (Dako, Denmark). The total concentration of MPO was determined using a calibration curve constructed using standard solutions of the enzyme. The results are expressed as three indices: the total level of MPO $(\mathrm{ng} / \mathrm{ml})$, the level of active MPO $(\mathrm{ng} / \mathrm{ml})$ and the relative amount of active MPO (\%), calculated by the formula:

active MPO $(\%)=($ active MPO concentration $\times$ $\times 100) /$ total MPO concentration.

Statistical analysis. All data are presented as the mean and standard deviation. Baseline characteristics between two groups, as well as data before and after the intervention were compared using Student $t$-test and the Mann-Whitney U test for normally and non-normally distributed data, respectively. A $P$ value $\leq 0.05$ was considered statistically significant.

\section{Results and Discussion}

Medicinal plants included in polyherbal composition (PC) are characterized by potent immunomodulatory and anti-inflammatory activities [10]. Qualitative and quantitative phytochemical analysis of PC revealed tannins, saponins, flavonoids, water soluble and water insoluble phenolic compounds, cardiac glycosides and cumarins. Most predominant fatty acids were octadecadienoic (11.46 mg/g), octadecatrienoic (10.61 mg/g) and hexadecanoic $(7.04 \mathrm{mg} / \mathrm{g})$. No cytotoxic effect of PC was detected in our previous experiments in vitro [11]. Our results showed that the cholesterol, ALT and AST baseline serum levels significantly exceed the reference values in all patients with chronic cholecystitis, especially in woman (Table 2). Deviations from the norm in the levels of these indexes especially cholesterol were more pronounced in patients with calculous cholecystitis (data not shown).

Numerous clinical observations revealed positive association between the increased serum level of cholesterol and cholelithiasis [12]. Increased ALT and AST levels are also indicators of cholestasis [13], which along with elevated cholesterol serum level promote cholelithiasis and gallbladder inflammation. Additional risk factor of cholelithiasis is elevated serum level of unconjugated bilirubin in all study participants, since presence of unconjugated bilirubin plays an important part in the formation of cholesterol gallstones [14]. Treatment with polyherbal tea resulted in the normalization of mentioned biochemical constants in all patients with chronic 
Ta b le 2. Effect of water extract from polyherbal composition on serum biochemical indices of patients with chronic cholecystitis

\begin{tabular}{|c|c|c|c|}
\hline Biochemical index & Reference values & Baseline value & Post-intervention value \\
\hline \multicolumn{4}{|c|}{ Female, $n=48$ (age range 22-70 years) } \\
\hline Cholesterol, mg/dl & $<200$ & $247.3 \pm 37.1^{*}$ & $189.6 \pm 9.4^{\#}$ \\
\hline ALT, IU/l & 34 & $51.2 \pm 12.6^{*}$ & $34.5 \pm 2.6^{\#}$ \\
\hline AST, IU/l & 31 & $44.1 \pm 7.4^{*}$ & $30.1 \pm 2.4^{\#}$ \\
\hline $\mathrm{TBR}, \mu \mathrm{mol} / 1$ & $8-20$ & $23.6 \pm 4.2^{*}$ & $17.5 \pm 1.1$ \\
\hline Conjugated bilirubin, $\mu \mathrm{mol} / 1$ & $0-5$ & $4.8 \pm 0.7$ & $3.9 \pm 0.6$ \\
\hline Unconjugated bilirubin, $\mu \mathrm{mol} / 1$ & $<15$ & $18.8 \pm 3.8^{*}$ & $13.5 \pm 0.6^{\#}$ \\
\hline \multicolumn{4}{|c|}{ Male, $n=28$ (age range 20-62 years) } \\
\hline Cholesterol, mg/dl & $<200$ & $256.0 \pm 35.3^{*}$ & $191.6 \pm 7.1^{\#}$ \\
\hline ALT, IU/l & 45 & $53.5 \pm 8.0^{*}$ & $39.0 \pm 3.3^{\#}$ \\
\hline AST, IU/l & 41 & $41.9 \pm 4.2$ & $33.1 \pm 1.5^{\#}$ \\
\hline TBR, $\mu \mathrm{mol} / 1$ & $8-20$ & $23.2 \pm 3.1^{*}$ & $17.4 \pm 0.8^{\#}$ \\
\hline Conjugated bilirubin, $\mu \mathrm{mol} / 1$ & $0-5$ & $4.8 \pm 0.5$ & $3.8 \pm 0.5$ \\
\hline Unconjugated bilirubin, $\mu \mathrm{mol} / 1$ & $<15$ & $18.0 \pm 2.4^{*}$ & $13.0 \pm 1.1^{\#}$ \\
\hline
\end{tabular}

*The index is higher than reference values; ${ }^{*} P<0.05$ as compared to the baseline value.

cholecystitis regardless of the form of the disease (calculous or acalculous).

Clinical data on hematologic indices in the course of chronic cholecystitis are sparse, since this form of the disease doesn't related to acute inflammation and dramatical changes in leukocyte count and proportions. In our experiments, total leukocyte count was slightly higher than upper value of reference range. It indicates low-grade or meta-inflammation that is typical for chronic diseases including hepatobiliary disorders [15].

Slightly elevated ESR was an additional indicator of low-grade inflammation in majority of study participants (Table 3). Fractions of leukocytes from different subpopulations didn't exceed control values. Though, baseline NLR ratio in our study participants with chronic cholecystitis was higher than that characteristic for healthy subjects [16].

NLR is one of the most popular biomarkers in biological and medical research in recent years. Association of NLR with numerous chronic inflammatory diseases is widely reported. NLR is both methodologically simple and affordable, and thus has been increasingly used in clinical trials and research studies. As mentioned above [3], NLR is considered informative marker of cholecystitis severity. In this study, NLR was significantly higher, when compared to the reference values, only in patients with calculous cholecystitis (data not shown). Treatment with polyherbal tea resulted in the decrease of total leukocyte count to the middle value of the reference range. NLR after the tea consumption was lower than baseline value (1.8 times in male patients and 1.3 times - female) and didn't differ from reported in the literature normal values.

It should be noted, that significant individual variability in NLR and ESR was registered in the patients with acalculous cholecystitis. Comparative analysis of biochemical and hematological indexes of the patients did not reveled age-dependent differences both before and after consumption of polyherbal composition (data not shown).

Meta-inflammation is associated with moderate changes in local (in inflammed tissue) and systemic (in blood serum) cytokine profile [2]. In our experiments, three cytokines were examined: IL1 $\beta$, IL6 and IL4. The examination was performed in three time poins: before the intervention, 30 days after the start of tea consumption and at the end of the course of tea consumption. Our results have showed, that serum levels of all investigated cytokines were within reference rate but higher than median values stated by the manufacturer (Table 4). It is necessary to point that clinical investigation of blood donors by another research groups with the use of the same cytokine ELISA kits revealed higher values for healthy 
Table 3. Effect of water extract from polyherbal composition on haematological indices of patients with chronic cholecystitis

\begin{tabular}{|c|c|c|c|}
\hline Biochemical index & Reference values & Baseline value & $\begin{array}{c}\text { Post-intervention } \\
\text { value }\end{array}$ \\
\hline \multicolumn{4}{|c|}{ Female, $n=49$ (age range 22-70 years) } \\
\hline Total leukocytes, $10^{9} / \mathrm{l}$ & $4-9$ & $10.6 \pm 2.9^{*}$ & $7.6 \pm 0.9$ \\
\hline Monocytes, \% & $3-11$ & $4.2 \pm 0.9$ & $5.5 \pm 1.3$ \\
\hline Eosinophils, \% & $0-5$ & $4.4 \pm 1.2$ & $3.3 \pm 0.7$ \\
\hline Segmented neutrophils, \% & $45-70$ & $58.6 \pm 3.2$ & $55.9 \pm 3.1$ \\
\hline Band neutrophils, \% & $1-5$ & $4.2 \pm 1.0$ & $3.5 \pm 0.6$ \\
\hline Lymphocytes, \% & $18-40$ & $29.2 \pm 2.3$ & $30.6 \pm 2.8$ \\
\hline NLR & $1.6^{[16]}$ & $2.3 \pm 0.4$ & $1.8 \pm 0.1$ \\
\hline ESR, $\mathrm{mm} / \mathrm{hr}$ & Women $<50$ years old: $<20$ & $21.2 \pm 3.4^{*}$ & $10.6 \pm 1.9^{\#}$ \\
\hline $\mathrm{ESR}, \mathrm{mm} / \mathrm{hr}$ & Women $\geq 50$ years old: $<30$ & $23.7 \pm 4.8$ & $10.9 \pm 2.8^{\#}$ \\
\hline \multicolumn{4}{|c|}{ Male, $n=28$ (age range 20-62 years) } \\
\hline Total leukocytes, $10^{9} / 1$ & $4-9$ & $10.6 \pm 2.7^{*}$ & $7.2 \pm 1.1$ \\
\hline Monocytes, \% & $3-11$ & $4.3 \pm 0.8$ & $5.7 \pm 1.2^{*}$ \\
\hline Eosinophils, \% & $0-5$ & $4.8 \pm 1.3$ & $3.6 \pm 0.6$ \\
\hline Segmented neutrophils, \% & $45-70$ & $60.4 \pm 3.8$ & $54.7 \pm 2.7$ \\
\hline Band neutrophils, \% & $1-5$ & $3.5 \pm 1.1$ & $3.5 \pm 0.8$ \\
\hline Lymphocytes, \% & $18-40$ & $27.6 \pm 3.1$ & $31.5 \pm 2.3$ \\
\hline NLR & $1.6^{[16]}$ & $2.8 \pm 0.3$ & $1.6 \pm 0.2^{\#}$ \\
\hline $\mathrm{ESR}, \mathrm{mm} / \mathrm{h}$ & Men $<50$ years old: $<15$ & $18.5 \pm 2.9^{*}$ & $9.6 \pm 2.1^{\#}$ \\
\hline $\mathrm{ESR}, \mathrm{mm} / \mathrm{h}$ & Men $\geq 50$ years old: $<20$ & $22.0 \pm 1.0 *$ & $8.3 \pm 0.7^{\#}$ \\
\hline
\end{tabular}

*The index is higher than reference values; ${ }^{*} P<0.05$ as compared to the baseline value.

Table 4. Effect of water extract from polyherbal composition on serum cytokine levels in patients with chronic cholecystitis

\begin{tabular}{|c|c|c|c|c|c|}
\hline Cytokine & Control & & Baseline & 30 days & 45 days \\
\hline \multirow{2}{*}{ IL1 $\beta$} & $1.6 \pm 0.2^{(0-11)}$ & Female, $n=20$ & $6.2 \pm 2.1^{*}$ & $4.4 \pm 1.9^{*}$ & $5.2 \pm 1.4^{*}$ \\
\cline { 2 - 6 } & $3.6 \pm 1.0^{[17]}$ & Male, $n=11$ & $8.0 \pm 3.5^{*}$ & $5.6 \pm 1.9^{*}$ & $5.0 \pm 2.0^{*}$ \\
\hline \multirow{2}{*}{ IL6 } & $2.1 \pm 0.3^{(0-10)}$ & Female, $n=20$ & $3.9 \pm 1.5$ & $2.0 \pm 0.7$ & $1.9 \pm 0.5 \#$ \\
\cline { 2 - 6 } & $4.7 \pm 0.9^{[17]}$ & Male, $n=11$ & $5.3 \pm 1.9^{*}$ & $2.7 \pm 1.0$ & $1.9 \pm 0.5 \#$ \\
\hline \multirow{2}{*}{ IL4 } & $0.2 \pm 0.02^{(0-4)}$ & Female, $n=20$ & $3.7 \pm 1.6^{*}$ & $3.3 \pm 1.7^{*}$ & $4.9 \pm 2.3^{*}$ \\
\cline { 2 - 6 } & $0.6 \pm 0.2^{[17]}$ & Male, $n=11$ & $4.5 \pm 2.0^{*}$ & $3.7 \pm 2.0^{*}$ & $4.0 \pm 1.9^{*}$ \\
\hline
\end{tabular}

${ }^{*} P<0.05$ as compared to the reference values; ${ }^{*} P<0.05$ as compared to the baseline value.

persons as compared to those stated by the manufacturer [17].

Increased serum levels of IL1 $\beta$, IL6 indicate systemic inflammation. IL6 is considered as a 'metabolic hormone' and an attractive target for the treatment of metabolic diseases, since increased level of this cytokine is regarded as a biomarker of systemic inflammation and metabolic disorders [18]. Consumption of polyherbal tea was associated with progressive decrease of IL6 serum level. Serum level of IL1 $\beta$ didn't change in the study participants after the polyherbal tea consumption. One of the probably 
Ta b le 5. Effect of water extract from polyherbal composition on myeloperoxidase activity in patients with chronic cholecystitis

\begin{tabular}{|l|c|c|c|c|c|}
\hline \multicolumn{1}{|c|}{ Parameter } & Control & & Baseline & 30 days & 45 days \\
\hline \multirow{2}{*}{ MPO protein, $\mathrm{ng} / \mathrm{ml}$} & \multirow{2}{*}{$10.6 \pm 4.3$} & Female, $n=20$ & $20.2 \pm 7.1^{*}$ & $22.8 \pm 7.9^{*}$ & $18.2 \pm 6.4$ \\
\cline { 3 - 6 } & & Male, $n=11$ & $23.9 \pm 8.5^{*}$ & $39.6 \pm 9.4^{*}$ & $23.6 \pm 10.0^{*}$ \\
\hline \multirow{2}{*}{ MPO activity, ng/ml } & \multirow{2}{*}{$4.6 \pm 1.8$} & Female, $n=20$ & $2.4 \pm 0.9$ & $3.7 \pm 1.0$ & $2.3 \pm 0.2^{*}$ \\
\cline { 3 - 6 } & & Male, $n=11$ & $4.2 \pm 1.9$ & $8.5 \pm 3.2^{*}$ & $2.3 \pm 0.2^{* \#}$ \\
\hline \multirow{2}{*}{ Spesific activity of MPO, \% } & \multirow{2}{*}{$58.7 \pm 20.3$} & Female, $n=20$ & $16.7 \pm 5.6^{*}$ & $20.3 \pm 8.2^{*}$ & $13.5 \pm 4.3^{*}$ \\
\cline { 3 - 6 } & & Male, $n=11$ & $20.8 \pm 7.3^{*}$ & $19.7 \pm 8.0^{*}$ & $12.1 \pm 4.9^{*}$ \\
\hline
\end{tabular}

${ }^{*} P<0.05$ as compared to the healthy person's values; ${ }^{*} P<0.05$ as compared to the baseline value.

reasons of this phenomenon can be the involvement of this cytokine in reparative processes in soft tissues [19].

Increased IL4 in blood serum can be the indicator of Th2 inflammation that is characteristic for the allergies, helminth infection etc. [20]. In addition, elevated IL4 level can evidence compensatory immune system response to chronic Th1 inflammatory process in order to induce alternative polarization of circulating and tissue mononuclear phagocytes, which are necessary for the tissue regeneration and inflammation resolution [21]. In our experiments, baseline serum level of IL4 was higher than normal values in all patients with chronic cholecystitis (Table 4). At the end of the course of polyherbal tea consumption, serum concentration of this cytokine was slightly increased. We incline to believe that slight increase in IL4 level along with the decrease in IL6 concentration can evidence anti-inflammatory effect of the intervention.

MPO is a well-known neutrophil enzyme, primarily released by activated cells and is characterized by potent pro-oxidative and proinflammatory properties. It is packaged in the azurophilic granules of neutrophils. The vital role of MPO is the host innate defense by the synthesis of oxidants such as hypochlorous acid. MPO is also released into the extracellular space during chronic inflammatory processes when neutrophils are activated and degranulate in the aseptic condition. In such cases, generated oxidants have significant potential to damage host tissue and are associated with many inflammatory diseases [22]. Currently, the level of circulating MPO is considered as an informative diagnostic and prognostic biomarker of pathological states associated with acute or chronic inflammation [23]. In our study, baseline total MPO level in blood plasma of patients with chronic cholecystitis was significantly higher than that in healthy persons, especially in male patients (Table 5). At the same time, the percentage of active MPO was substantially decreased in all female patients. It can indicate metabolic exhaustion of innate immune cell associated with compensatory anti-inflammatory response syndrome (CARS), which is characteristic for the prolonged inflammatory processes, and can create a risk of opportunistic infections [24].

Polyherbal tea consumption was accompanied by transitory slight elevation of the levels of total and active form of MPO in blood plasma. However, indices of patients with chronic cholecystitis were still higher than those in healthy persons. At the end of tea course, all investigated parameters of plasma MPO did not differ significantly from corresponding baseline values.

In conclusion, our preliminary results suggest that a 45-day consumption of polyherbal tea consisting of eight medicinal plants including $P$. oleracea causes the normalization of liver biochemical indices, diminution of hematological and immunological signs of systemic inflammation, and in such a way can reduce the severity of chronic cholecystitis. Normalization of laboratory parameters was accompanied by the improvements in clinical outcome in $77.6 \%$ of participants (59 patients) as was confirmed by the results of ultrasonography and patient surveys. Clinical deterioration and/or adverse effects were not detected. These results give reasons to recommend investigated polyherbal tea as a component of complementary therapy for patients with this hepatobiliary disorder. Further studies with extended patient group are needed to elucidate comprehensively differences in the response to the polyherbal tea consumption in male and female patients. 
Conflict of interest. Authors have completed the Unified Conflicts of Interest form at http://ukrbiochemjournal.org/wp-content/uploads/2018/12/ coi_disclosure.pdf and declare no conflict of interest.

The study was supported by the Ministry of Education and Science of Ukraine (Project state registration No 0116U002527).

\section{ПРОТИЗАПАЛЬНИЙ ТА ГЕПАТОПРОТЕКТОРНИЙ ЕФЕКТИ ПОЛІГЕРБАЛЬНОЇ КОМПОЗИЦЇ̈ В ПАЦІЕНТІВ ІЗ ХРОНІЧНИМ ХОЛЕЦИСТИТОМ}

$$
\begin{aligned}
& \text { М. Гахраманова }{ }^{1,2} \text {, І. Халілова }{ }^{3} \text {, А. Омаров } 3 \text {, } \\
& \text { Я. Сусак }{ }^{4}, \text { М. Рудик², Л. Сківка }{ }^{2 \bowtie} \\
& { }^{1} \text { Медичний центр Наргіз, Баку, } \\
& \text { Республіка Азербайджан; } \\
& { }^{2} \text { ННЦ «Інститут біології та медицини», } \\
& \text { Київський національний університет } \\
& \text { імені Тараса Шевченка, Україна; } \\
& { }^{3} \text { Кафедра біологічних наук \& Центр } \\
& \text { дослідження клітинної патології, Університет } \\
& \text { Хазар, Баку, Республіка Азербайджан; } \\
& { }^{4} \text { Національний медичний університет } \\
& \text { ім. О. О. Богомольця, Київ, Україна; } \\
& \text { 凶e-mail: realmed@i.com.ua }
\end{aligned}
$$

Препарати рослинного походження широко застосовуються у разі комплементарного лікування запальних захворювань, у т.ч. розладів гепатобіліарної системи, серед яких хронічний холецистит $€$ одним із найпоширеніших. Метою роботи було дослідити вплив полігербальної композиції, яка містила 8 лікарських рослин (Helichrysum arenarium, Mentha piperita, Calendula officinalis, Taraxacum officinale, Polygonum aviculare, Matricaria chamomilla, Portulaca oleracea, Hypericum perforatum), на біохімічні та гематологічні показники, а також на параметри імунної реактивності в пацієнтів із хронічним холециститом. Встановлено, що споживання ними полікомпонентного чаю протягом 45 днів нормалізувало біохімічні показники печінки (рівень холестеролу, АЛТ, АСТ, загального та некон'югованого білірубіну в сироватці крові) та зменшувало гематологічні (лейкоцитоз, підвищення ШОЕ та значення нейтрофільно-лімфоцитарного коефіцієнта), а також імунологічні (підвищений сироватковий рівень прозапальних цитокінів) показники системного запалення.
Зроблено припущення, що досліджена полігербальна композиція може бути рекомендована для застосування у комплементарній терапії хворих на хронічний холецистит.

К лючов і слова: хронічний холецистит, полігербальна композиція, холестерол, цитокіни, гепатопротекторна дія, імуномодуляція.

\section{References}

1. Lammert F, Gurusamy K, Ko CW, Miquel JF, Méndez-Sánchez N, Portincasa $\mathrm{P}$, van Erpecum KJ, van Laarhoven CJ, Wang DQ. Gallstones. Nat Rev Dis Primers. 2016; 2(1): 16024.

2. Kasprzak A, Szmyt M, Malkowski W, Przybyszewska W, Helak-Łapaj C, SeraszekJaros A, Surdacka A, Małkowska-Lanzafame A, Kaczmarek E. Analysis of immunohistochemical expression of proinflammatory cytokines (IL$1 \alpha$, IL-6, and TNF- $\alpha$ ) in gallbladder mucosa: comparative study in acute and chronic calculous cholecystitis. Folia Morphol (Warsz). 2015; 74(1): 65-72.

3. Micić D, Stanković S, Lalić N, Đukić V, Polovina S. Prognostic value of preoperative neutrophil-to-lymphocyte ratio for prediction of severe cholecystitis. J Med Biochem. 2018; 37(2): 121-127.

4. Latief U, Ahmad R. Herbal remedies for liver fibrosis: A review on the mode of action of fifty herbs. J Tradit Complement Med. 2017; 8(3): 352-360.

5. Farkhondeh T, Samarghandian S, AzimiNezhad M, Hozeifi S. The hepato-protective effects of Portulaca oleracea L. extract: review. Curr Drug Discov Technol. 2019;1 6(2): 122-126.

6. Iranshahy $M$, Javadi $B$, Iranshahi $M$, Jahanbakhsh SP, Mahyari S, Hassani FV, Karimi G. A review of traditional uses, phytochemistry and pharmacology of Portulaca oleracea L. J Ethnopharmacol. 2017; 205: 158172.

7. Yang Y, Zhang Z, Li S, Ye X, Li X, He K. Synergy effects of herb extracts: pharmacokinetics and pharmacodynamic basis. Fitoterapia. 2014; 92: 133-147.

8. Gakhramanova M., Gakhramanov S. Collection of medicinal plants with hepatoprotective, choleretic and anti-inflammatory effects. Eurasian patent for invention no 201300492. Published 30.05.2014. 
9. Franck $\mathrm{T}$, Kohnen $\mathrm{S}$, Boudjeltia $\mathrm{KZ}$, Van Antwerpen P, Bosseloir A, Niesten A, Gach O, Nys M, Deby-Dupont G, Serteyn D. A new easy method for specific measurement of active myeloperoxidase in human biological fluids and tissue extracts. Talanta. 2009; 80(2): 723-729.

10. George A, Chinnappan S, Choudhary Y, Bommu P, Sridhar M. Immunomodulatory activity of an aqueous extract of Polygonum minus huds on Swiss albino mice using carbon clearance assay. Asian Pac J Trop Dis. 2014; 4(5): 398-400.

11. Gakhramanova M, Molozhava O, Svyatetska V, Ostapchuk A, Skivka L. Phytochemical analysis and immunomodulatory effect of polyherbal preparation with hepatoprotective, choleretic and anti-inflammatory activity in vitro. Proc. III Intern. Scientific Conf. "Microbiology and Immunology - the Development Outlook in the 21st century". Kyiv, Ukraine, 2018. P. 133.

12. Pak M, Lindseth G. Risk Factors for Cholelithiasis. Gastroenterol Nurs. 2016; 39(4): 297-309.

13. Ahn KS, Yoon YS, Han HS, Cho JY. Use of liver function tests as first-line diagnostic tools for predicting common bile duct stones in acute cholecystitis patients. World J Surg. 2016; 40(8): 1925-1931.

14. Berman MD, Carey MC. Metastable and equilibrium phase diagrams of unconjugated bilirubin IX $\alpha$ as functions of $\mathrm{pH}$ in model bile systems: Implications for pigment gallstone formation. Am J Physiol Gastrointest Liver Physiol. 2015; 308(1): G42-G55.

15. Castro AM, Macedo-de la Concha LE, PantojaMeléndez CA. Low-grade inflammation and its relation to obesity and chronic degenerative diseases. Revista Médica del Hospital General de México. 2017; 80(2): 101-105.

16. Lee JS, Kim NY, Na SH, Youn YH, Shin CS. Reference values of neutrophil-lymphocyte ratio, lymphocyte-monocyte ratio, platelet- lymphocyte ratio, and mean platelet volume in healthy adults in South Korea. Medicine (Baltimore). 2018; 97(26): e11138.

17. Gadzhiev DzhN, Gadzhiev NDzh, Mamedova ZB. Features of cytokines profile in various forms of systemic inflammatory response syndrome in patients with acute calculous cholecystitis. Khirurgiia (Mosk). 2017; (10): 61-64. (In Russian).

18. Ghanemi A, St-Amand J. Interleukin- 6 as a "metabolic hormone". Cytokine. 2018; 112: 132136.

19. Hasegawa T, Hall CJ, Crosier PS, Abe G, Kawakami K, Kudo A, Kawakami A. Transient inflammatory response mediated by interleukin$1 \beta$ is required for proper regeneration in zebrafish fin fold. Elife. 2017;6. pii: e22716.

20. Gandhi NA, Bennett BL, Graham NMH, Pirozzi G, Stahl N, Yancopoulos GD. Targeting key proximal drivers of type 2 inflammation in disease. Nat Rev Drug Discov. 2016; 15(1): 3550.

21. Van Dyken SJ, Locksley RM. Interleukin-4- and interleukin-13-mediated alternatively activated macrophages: roles in homeostasis and disease. Annu Rev Immunol. 2013; 31: 317-343.

22. Bonaventura A, Liberale L, Carbone F, Vecchié A, Diaz-Cañestro C, Camici GG, Montecucco F, Dallegri F. The pathophysiological role of neutrophil extracellular traps in inflammatory diseases. Thromb Haemost. 2018; 118(1): 6-27.

23. Coculescu BI, Dincă GV, Bălăeț C, Manole G, Bălăeț M, Stocheci CM. Myeloperoxidase, a possible biomarker for the early diagnosis of cardiac diastolic dysfunction with preserved ejection fraction. $J$ Enzyme Inhib Med Chem. 2018; 33(1): 1292-1298.

24. Ward NS, Casserly B, Ayala A. The compensatory anti-inflammatory response syndrome (CARS) in critically ill patients. Clin Chest Med. 2008; 29(4): 617-625. 